\title{
ANALISIS NOVEL GURU AINI KARYA ANDRE HIRATA DENGAN PENDEKATAN OBJEKTIF
}

\author{
Zherry Putria Yanti ${ }^{1}$, Atika Gusriani ${ }^{2}$ \\ Prodi Pendidikan Bahasa Indonesia \\ STKIP Adzkia, Jl. Taratak Paneh No.7 Korong Gadang, Kalumbuak, Kec. \\ Kuranji, Kota Padang, Sumatera Barat 25175 \\ Surel: zherryputriayanti@gmail.com ${ }^{1}$, gusrianiatika@gmail.com ${ }^{2}$
}

\begin{abstract}
Abstrak
Penelitian ini membahas tentang nilai pendidikan dalam novel Guru Aini terkait Pembelajaran Bahasa Indonesia. Adapun tujuan yang ingin dicapai adalah untuk mendeskripsikan dan menganalisis nilai pendidikan apa saja yang terkandung dalamnya. Subjek penelitian ini adalah novel Guru Aini karya Andre Hirata. Penelitian difokuskan pada permasalahan yang berkaitan dengan nilai pendidikan. Data dianalisis menggunakan teknik deskripsi kualitatif dengan tujuan pengkajian dan pendeskripsian permasalahan yang diteliti. Unsur-unsur intrinsik dalam Novel Guru Aini meliputi tema, alur, tokoh, penokohan, latar, sudut pandang, gaya bahasa, dan amanat.
\end{abstract}

Kata Kunci : Pendekatan Objektif, Novel, Guru Aini

\begin{abstract}
This research discusses the value of education in Guru Aini's novel related to Indonesian Language Learning. The goal to be achieved is to describe and analyze the value of education what is contained in it. The subject of this study is the novel Guru Aini by Andre Hirata. Research is focused on issues related to the value of education. Data is analyzed using qualitative description techniques with the aim of assessing and describing the problems studied. The intrinsic elements in Guru Aini's novel include themes, plots, characters, characterization, setting, viewpoint, language style, and mandate.
\end{abstract}

Keywords: Objective Approach, Novel, Guru Aini

\section{A. PENDAHULUAN}

Novel menciptakan ilusi terhadap realitas aktual atau membuat dunia fiksi menjadi artificial agar perhatian kita terarah pada suatu hubungan yang imajinatif antara persoalan atau tema novel dan dunia nyata yang secara aktual kita hidupi (Atmazaki, 2007:39-40). Sedangkan menurut Semi (1988:24) novel mengungkapkan suatu konsentrasi kehidupan pada suatu saat yang tegang, dan pemusatan kehidupan yang tegas. Jadi dapat disimpulkan bahwa novel merupakan 
karya yang mengungkapkan aspek-aspek kemanusiaan yang lebih mendalam dan disajikan secara halus.

Novel Guru Aini adalah karya terbaru dari penulis Andrea Hirata. Novel ini terbit pada tahun 2020 oleh penerbit Bentang. Novel Andrea Hirata kebanyakan bercerita tentang pendidikan dan kehidupan orang pinggiran. Namun, dalam novel ini Andrea Hirata menghadirkan isi cerita yang berbeda. Dalam novel Guru Aini Andrea menghadirkan isi cerita yang mengandung unsur perjuangan seorang guru dalam mengajar siswanya.

Tujuan teori struktural adalah membongkar dan memaparkan secermat, seteliti, sedetail, dan sedalaman mungkin, keterkaitan dan keterjalinan semua unsur dalam karya sastra, yang bersama-sama menghasilkan makna yang secara menyeluruh membentuk makna yang penuh (Teeuw, 1984: 135). Novel Guru Aini karya Andrea Hirata terdiri dari unsur-unsur yang tentunya bersistem. Teori strukturalisme melihat bagaimana antarunsur tersebut saling mempengaruhi dan melihat seberapa besar kaitan dan pengaruh antar unsur tersebut. Oleh karena itu, novel Guru Aini karya Andrea Hirata dianalisis menggunakan teori strukturalisme.

Berdasarkan uraian di atas, maka penulis mengambil novel karya Andrea Hirata yang berjudul "Guru Aini” sebagai subjek penelitian, karena novel ini mempunyai daya tarik tersendiri bagi peneliti dimana kisah dalam cerita ini mengisahkan seorang perempuan yang memiliki cita-cita menjadi guru Matematika, ia tersinspirasi menjadi guru Matematika lantaran ayahnya sedang sakit. Sakit ayahnya bisa disembuhkan oleh ilmu kedokteran modern, hal ini membuat tokoh utama ingin sekali menjadi dokter dan untuk menjadi seorang dokter ia harus pintar Matematika. Di dalam novel "Guru Aini” ini juga terkandung nilai-nilai pendidikan karakter yang dapat diteladani oleh siswa dalam kehidupan sehari-hari. Berdasarkan penjelasan tersebut penulis tertarik untuk melakukan penelitian dengan judul "Analisis Novel Guru Aini Karya Andre Hirata dengan Pendekatan Objektif'. 


\section{B. KAJIAN TEORI}

Kata novel yang digunakan dalam bahasa Inggris dan diambil dari bahasa Italia, yaitu "novella" (sesuatu yang baru dan kecil, cerita dalam bentuk prosa. Hawthrome, Abrams (1971:110) menjelaskan bahwa novel lebih ditandai oleh kefiksiannya yang berusaha memberikan efek realis, dengan merepresentasikan karakter yang kompleks dengan motif yang bercampur dan berakar dalam kelas sosial, terjadi dalam struktur kelas sosial yang berkembang kearah yang lebih tinggi, interaksi dengan beberapa karakter lain, dan berkisah tentang kehidupan sehari-hari. Penulis novel memperlakukan karakter secara personal, dengan karakter memakai persona atau topeng sosialnya dan ia memerlukan kerangka masyarakat yang stabil (Atmazaki, 2007:39). Jadi, dapat dimpulkan novel merupakan gambaran kehidupan dan prilaku nyata yang ditulis dalam bentuk prosa.

Pendekatan Objektif ini tidak terlepas dari soal pengarang dan pembaca. Pendekatan ini memandang dan menelaah sastra dari segi intrinsik yang membangun suatu karya sastra, yaitu tema, tokoh dan penokohan, latar, alur, pen, gaya bahasa dan amanat. Perpaduan yang harmonis antara bentuk dan isi merupakan kemungkinan kuat untuk menghasilkan sastra yang bermutu Pendekatan objektif merupakan pendekatan yang paling penting sebab pendekatan apapun yang dilakukan pada dasarnya bertumpu pada karya sastra itu sendiri. Pendekatan ini memusatkan perhatian semata-mata pada unsur-unsur yang dikenal dengan analisis intrinsik. Melalui pendekatan objektif, unsur-unsur intrinsik akan dieksploitasi secara maksimal. Jadi, dapat disimpulkan bahwa pendekatan objektif adalah pendekatan yang dilakukan untuk melihat eksistensi sastra itu sendiri.

\section{METODE PENELITIAN}

Metode yang digunakan pada analisis ini adalah metode kualitatif. Metode kualitatif adalah metode yang berupaya untuk menyajikan dunia sosial, dan perspektifnya di dalam dunia, dari konsep, prilaku, persepsi, dan persoalan tentang manusia yang diteliti. Metode ini juga bermaksud untuk memahami fenomena tentang apa yang dialami subjek penelitian misalnya prilaku, persepsi, 
motivasi, tindakan. Selain itu penelititian kualitatif merupakan penelitian yang digunakan untuk menyelidiki, menggambarkan, menjelaskan, menemukan kualitas atau kesitimewaan dari pengaruh sosial yang tidak dapat dijelaskan atau digambarkan melalui pendekatan kuantitatif (Saryono, 2013).

Tujuan dilakukan penelitian ini adalah untuk menemukan dan mendalami unsur intrinsik yang terkandung di dalam novel Guru Aini. Baik dari segi tema, tokoh-penokohan, latar, alur, gaya bahasa dan sudut pandang yang ada dalam cerita tersebut. Dengan pemahaman secara mendalam mengenai unsuk instrinsik novel ini, maka akan memudahkan peneliti dalam menemukan nilai-nilai yang terkandung di dalamnya untuk diterapkan dalam kehidupan sehari-hari. Dalam penelitian ini objek yang dikaji adalah unsur intrinsik dalam novel Guru Aini karya Andre Hirata. Teknik analisis data yang peneliti lakukan adalah membaca novel "Guru Aini" dengan teliti dan mencatat tema, tokoh dan penokohan, latar, alur, gaya bahasa, sudut pandang dan amanat yang terkandung dalam novel tersebut.

\section{HASIL DAN PEMBAHASAN}

\section{Hasil dan pembahasan bisa dilihat dalam tabel berikut ini:}

\begin{tabular}{l|l|l}
\hline No & $\begin{array}{l}\text { Unsur } \\
\text { 1. }\end{array}$ & Tema \\
$\begin{array}{l}\text { Teminsik } \\
\text { keberanian dan hak yang sama dalam mendapatkan pendidikan. Hal ini } \\
\text { bisa terlihat dari perjalanan kisah seorang perempuan yang bernama } \\
\text { Desi Istiqomah yang mempunyai keberanian dalam mengabdi sebagai } \\
\text { guru matematika di sebuah pulau terpencil. Menurut desi pendidikan } \\
\text { memerlukan pengorbanan yang bernilai tetap, kosntan dan tak boleh } \\
\text { berubah. Dalam cerita ini Desi menemukan seorang siswa yang } \\
\text { mempunyai latar belakang kehidupan serba keterbatasan tetapi dia } \\
\text { seorang siswa yang pintar matematika sama sepertinya. Siswa tersebut } \\
\text { bernama Aini, ia seorang anak yang gigih dan pantang menyerah dalam } \\
\text { meraih cita-cita menjadi seorang dokter walaupun ayahnya sedang sakit, } \\
\text { hal itu menjadi pemicu semangat Aini sehingga ia bisa diterima di } \\
\text { fakultas ke kedokteran yang ia inginkan. }\end{array}$ \\
\hline
\end{tabular}




\begin{tabular}{|c|c|c|}
\hline 2. & $\begin{array}{l}\text { Tokoh \& } \\
\text { Penokohan }\end{array}$ & 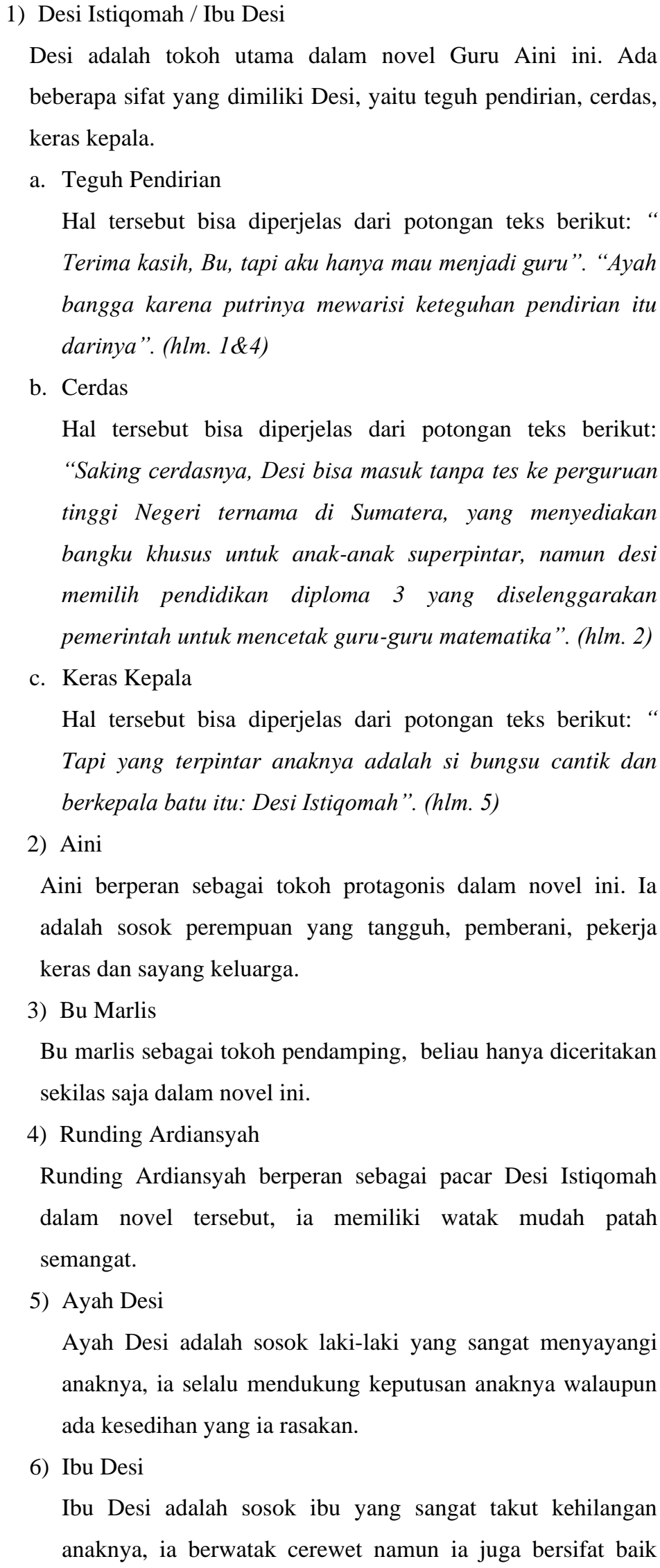 \\
\hline
\end{tabular}




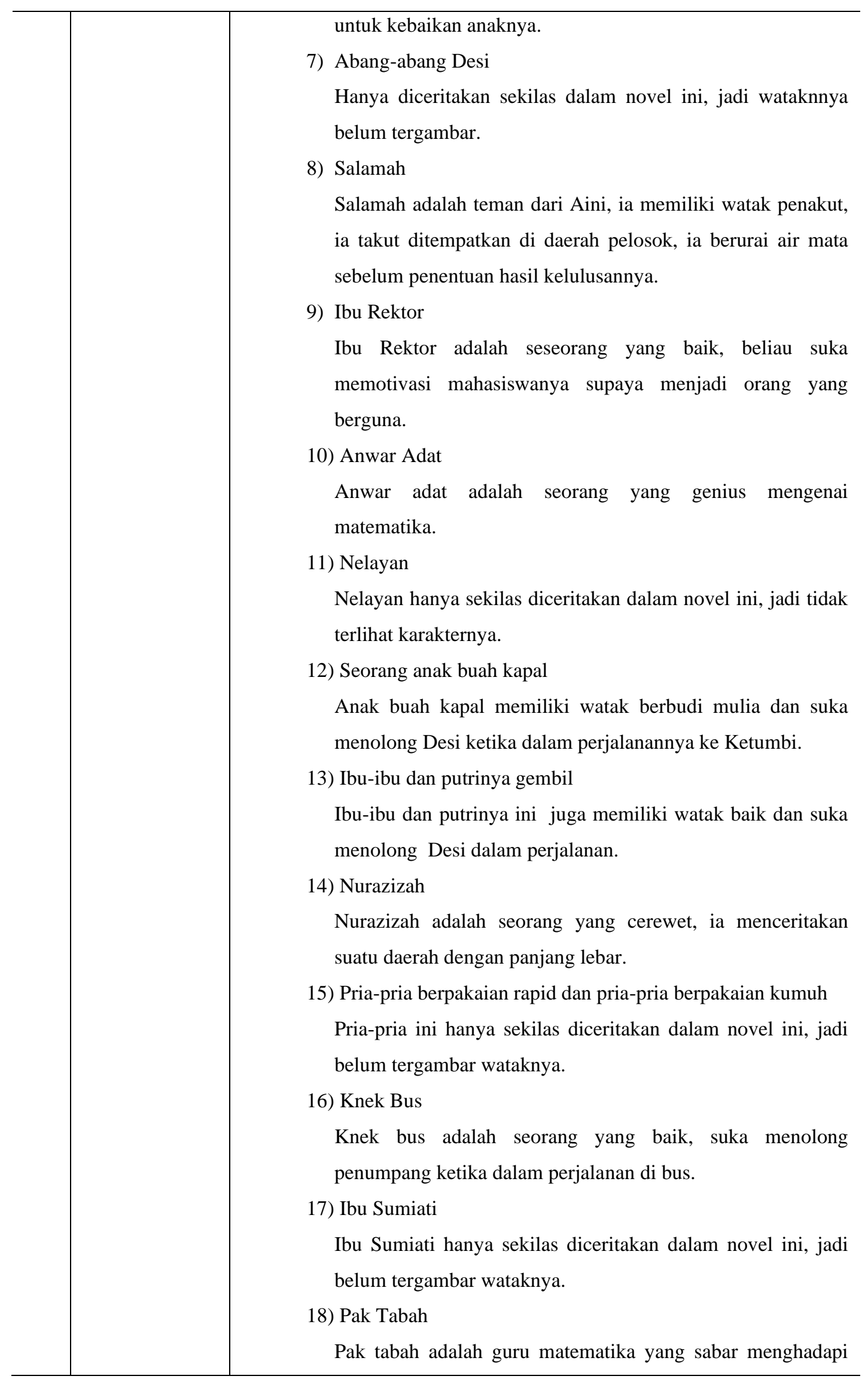




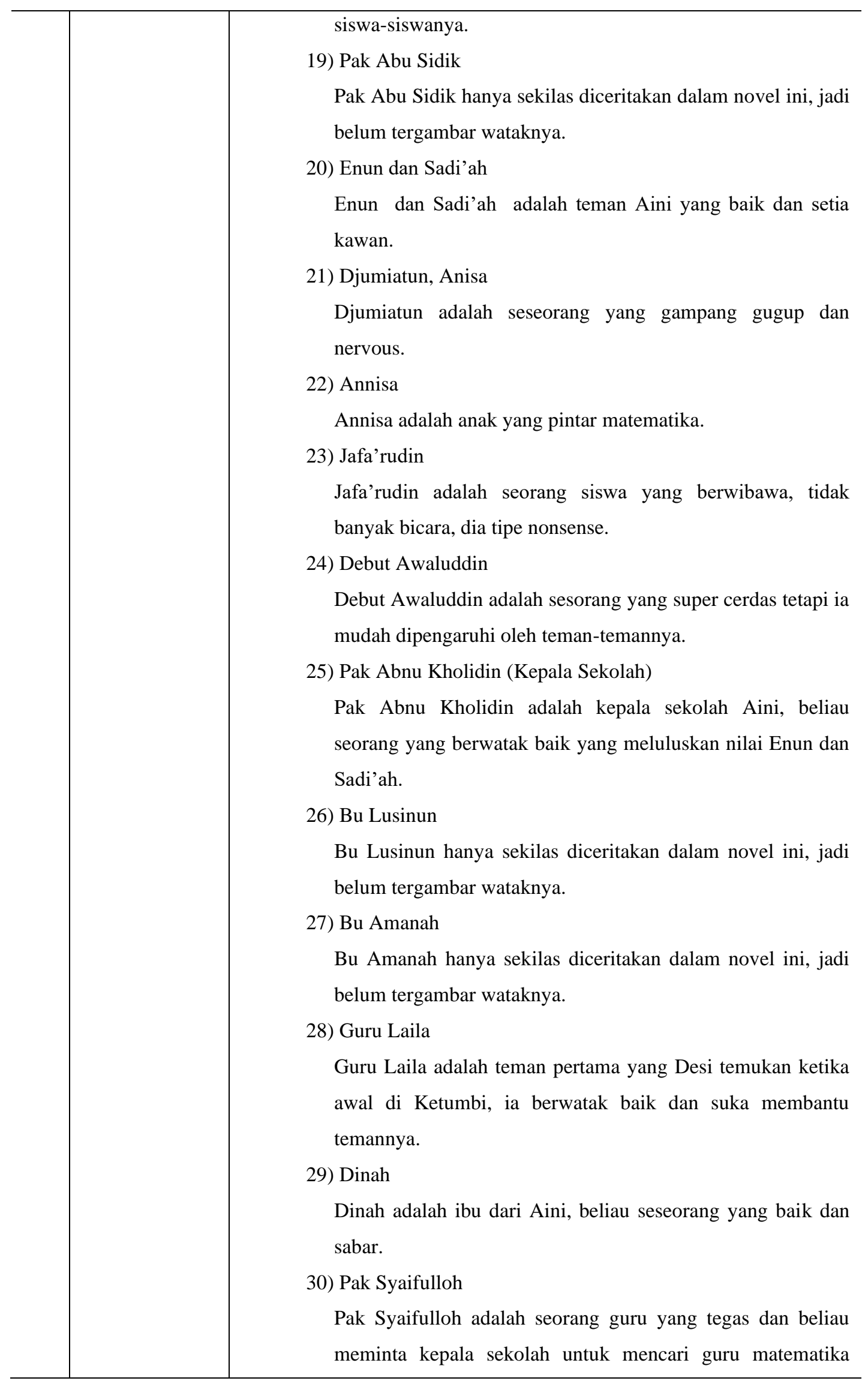




\begin{tabular}{|c|c|c|}
\hline & & $\begin{array}{l}\text { pengganti dirinya. } \\
\text { 31) Nadirah } \\
\text { Nadira merupakan murid favorit bagi guru-guru di } \\
\text { sekolahnya, ia bisa seni suara dan berwatak sangat baik. } \\
\text { 32) Afifah } \\
\text { Afifah seorang guru yang cerewet, pesimis dan sok tahu. } \\
\text { 33) Pak Cik dan Mak Cik } \\
\text { Pak cik dan Mak cik hanya sekilas diceritakan dalam novel } \\
\text { ini, jadi belum tergambar wataknya. } \\
\text { 34) } 3 \text { Pelayan Warung Kopi } \\
3 \text { pelayan warung kopi hanya sekilas diceritakan dalam novel } \\
\text { ini, jadi belum tergambar wataknya. } \\
\text { 35) Sila } \\
\text { Sila hanya sekilas diceritakan dalam novel ini, jadi belum } \\
\text { tergambar wataknya. }\end{array}$ \\
\hline 3. & Latar & $\begin{array}{l}\text { a. Latar Tempat } \\
\text { 1) Di sebuah rumah } \\
\text { Hal tersebut bisa diperjelas dari potongan teks berikut: } \\
\text { "Pembicaraan itu terjadi dalam sebuah rumah di satu kota } \\
\text { kecil di tengah pulau Sumatera sana”. (hal.2) } \\
\text { 2) Di Rumah Desi } \\
\text { Hal tersebut bisa diperjelas dari potongan teks berikut: “ Ibu } \\
\text { Amanah datang ke rumah Desi atau undangan Ibu Desi yang } \\
\text { sudah kehabisan cara untuk membujuk anak gadisnya”. (hlm. } \\
\text { 2) } \\
\text { 3) Di Kelas } \\
\text { Hal tersebut bisa diperjelas dari potongan teks berikut: “ } \\
\text { Semula ada } 180 \text { mahasiswa di kelas yang sangat kompetitif } \\
\text { itu”. (hlm. 7) } \\
\text { 4) Di Bus } \\
\text { Hal tersebut bisa diperjelas dari potongan teks berikut: } \\
\text { "Selanjutnya dia naik bus silih berganti dari satu kota ke } \\
\text { kota yang lain. (hlm. 14) } \\
\text { 5emalaman, Desi tidur di losmen di kota-kota kecil yang } \\
\text { dilewatinyalalu melanjutkan perjalanan naik aneka rupa } \\
\text { kendraan”. (hlm. 14) }\end{array}$ \\
\hline
\end{tabular}




\begin{tabular}{|c|c|}
\hline 6) Di Terminal \\
Hal tersebut bisa diperjelas dari potongan teks berikut: \\
"Akhirnya Desi sampai di terminal bus Palembang”. (hlm. \\
14) \\
7) Di Pelabuhan \\
Hal tersebut bisa diperjelas dari potongan teks berikut: \\
"Setelah 14 jam melayari sungai dan laut, Desi mencapai \\
Pelabuhan Kayu Arang di Pulau Bangka”. (hlm. 15) \\
8) Di Atas Kapal \\
Hal tersebut bisa diperjelas dari potongan teks berikut: \\
"Jangankan Desi yang baru dalam perjalanan itu saja \\
menumpang kapal, bahkan anak-anak buah kapal yang \\
sudah berpengalaman mengalami mabuk laut”. (hlm.16) \\
9) Di Jembatan \\
Hal tersebut bisa diperjelas dari potongan teks berikut: \\
"Mereka meninggalkan kapal lalu meniti jembatan menuju \\
10) Di Dermaga". (hal.18) \\
Hal termaga
\end{tabular}

Hal tersebut bisa diperjelas dari potongan teks berikut: " $D i$ dermaga itu Desi baru sadar bahwa dia telah memegang ember kaleng itu sejak dari kapal tadi”. (hal.18)

11) Di Depan Rumah Dinas

Hal tersebut bisa diperjelas dari potongan teks berikut: "Esoknya hari Minggu, bukan main ramainya orang di depan rumah dinas guru tipe 21 itu”. (hal.25)

12) Di Atas Motor

Hal tersebut bisa diperjelas dari potongan teks berikut: "Sore itu pula Laila memboncengkan Desi naik motor bebek ke pasar”. (hal.25)

13) Di Pasar

Hal tersebut bisa diperjelas dari potongan teks berikut: " $D i$ wartel di pasar, Desi menelpon orang tuanya”. (hlm.26)

14) Di Sekolah

Hal tersebut bisa diperjelas dari potongan teks berikut: “Tibala dia di sekolah". (hlm. 27)

b. Latar Waktu

1) Sore Hari

Hal tersebut bisa diperjelas dari potongan teks berikut: 


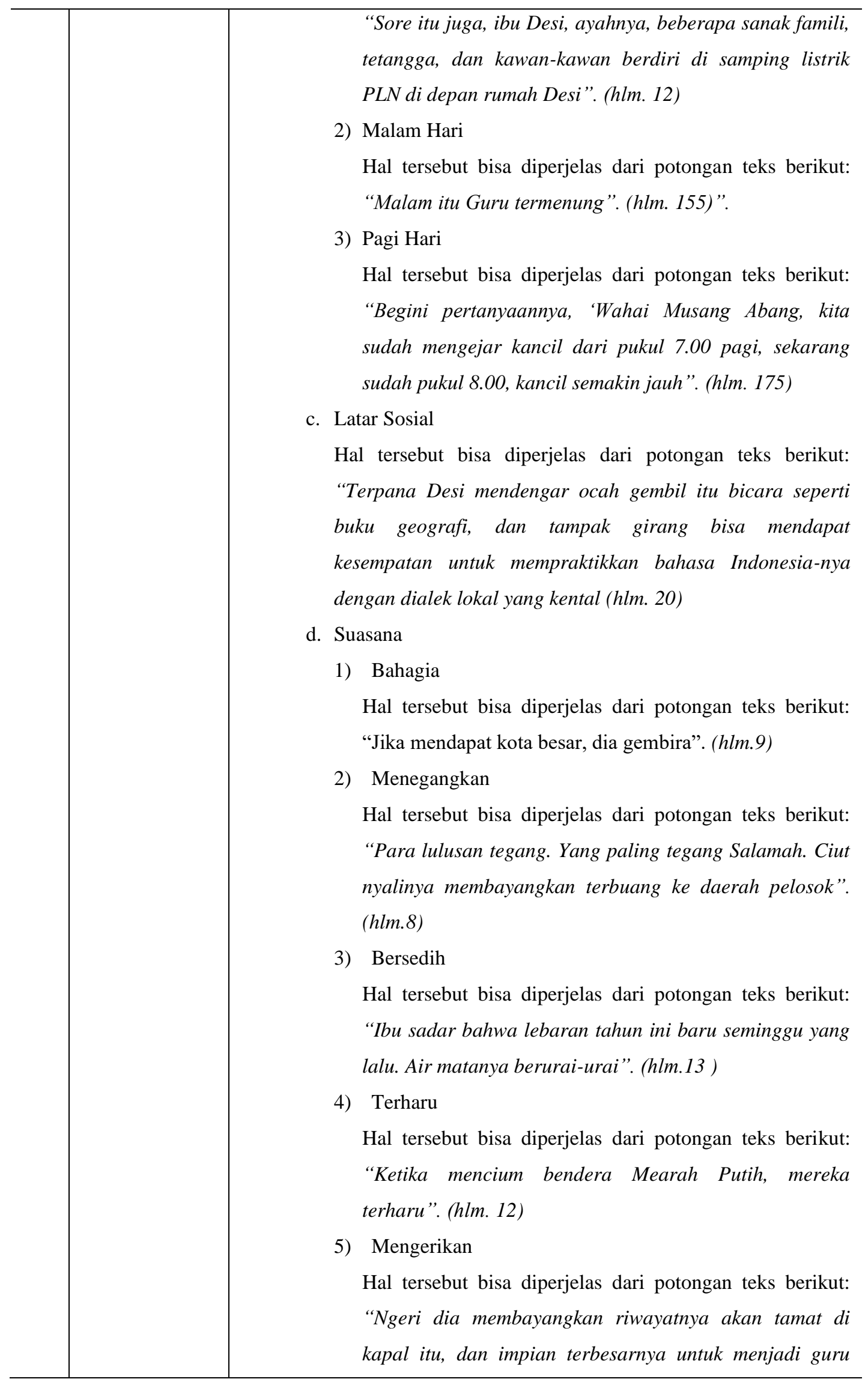




\begin{tabular}{|c|c|c|}
\hline & & $\begin{array}{l}\text { matematika di Pulau Tanjong Hampar tenggelam } \\
\text { bersama kapal ke dasar Selat Gaspar”. (hlm. 17) } \\
\text { 6) Damai } \\
\text { Hal tersebut bisa diperjelas dari potongan teks berikut: } \\
\text { “Tiba-tiba dia merasa tenang, damai”. (hlm. 22) } \\
\text { 7) Kecewa } \\
\text { Hal tersebut bisa diperjelas dari potongan teks berikut: } \\
\text { "Matematika akan membuatmu kecewa, ditinggalkan, } \\
\text { salah dimengerti, dicemburui, tak dikawani”. (hlm. 233) }\end{array}$ \\
\hline 4. & Alur & $\begin{array}{l}\text { Alur dalam novel guru Aini ini adalah menggunakan alur maju, } \\
\text { hal ini terlihat dari pengisahan cerita seorang guru matematika bernama } \\
\text { Desi Istiqomah memiliki prinsip yang teguh pendirian, walaupun ia } \\
\text { mengabdi ditempat terpelosok di daerah Ketumbi. Keadaan seperti ini } \\
\text { tidak membuat ia patah semangat dalam mengabdi sampai ia } \\
\text { menemukan seorang siswa yang bernama Aini yang juga pintar dalam } \\
\text { matematika seperti dirinya, sehingga Desi ini bisa mengantarkan } \\
\text { siswanya ke pintu kesuksesan. }\end{array}$ \\
\hline 5. & $\begin{array}{l}\text { Sudut } \\
\text { Pandang }\end{array}$ & $\begin{array}{l}\text { Sudut pandang yang digunakan dalam Novel Guru Aini karya } \\
\text { Andrea Hirata adalah sudut pandang orang ketiga serba tahu karena } \\
\text { penulis menceritakan apa saja yang terkait dengan tokoh. Seakan ia tahu } \\
\text { benar tentang watak, pikiran, perasaan, kejadian, dan latar belakang } \\
\text { yang mendalangi kejadian dalam kehidupan tokoh novel tersebut. Dalam } \\
\text { novel Guru Aini ini penulis juga menggunakan nama tokoh itu sendiri. } \\
\text { Jadi karena itulah sudut pandang orang ketiga serba tahu dikatakan } \\
\text { untuk novel ini. Hal tersebut dapat dibuktikan dengan potongan teks } \\
\text { berikut: } \\
\text { "Kini Aini tak pernah lagi dipanggil sebagai nama } \\
\text { terakhir untuk menerima buku ulangan matematika, } \\
\text { karena secara elegan posisinya telah digantikan secara } \\
\text { bergantian oleh Muhtadin, Antonidin, dan pastinya, } \\
\text { Djumiatun Ejaan lama.". (hlm.190) }\end{array}$ \\
\hline 6. & Gaya Bahasa & $\begin{array}{l}\text { Gaya bahasa yang digunakan dalam novel Guru Aini Karya } \\
\text { Andrea Hirata menggunakan bahasa Indonesia yang baik dan juga ada } \\
\text { bahasa-bahasa yang menggunakan majas untuk memperindah suatu } \\
\text { cerita. Bahasa yang digunakan mudah dipahami pembaca dan } \\
\text { mengandung nilai-nilai kesantunan yang dapat ditiru oleh pembaca. Hal } \\
\text { tersebut bisa diperjelas dari potongan teks berikut: } \\
\text { a. Majas Metafora }\end{array}$ \\
\hline
\end{tabular}




\begin{tabular}{|c|c|c|}
\hline & & $\begin{array}{l}\text { - "Tapi yang terpintar dari ketiga anaknya adalah si } \\
\text { bungsu cantik berkepala batu itu: Desi Istiqomah". } \\
\text { (hlm.5) } \\
\text { b. Majas Hiperbola } \\
\text { - "Salamah mengambil kertas undiannya dengan } \\
\text { langkah macam kakinya dibebani seribu batu". } \\
\text { (hlm.8) } \\
\text { "Dadanya mau meledak". Setelah berbulan-bulan } \\
\text { bersusah payah, bersimbah keringat dan air mata } \\
\text { untuk memenangkan hati Guru Desi benar-benar } \\
\text { menerimanya". (hlm.170) } \\
\text { c. Majas Personifikasi } \\
\text { "Jangankan ditampar gelombang musim barat, } \\
\text { melihat kapal kayu itu saja, dia sudah merasa } \\
\text { mabuk". (hlm 16) }\end{array}$ \\
\hline 7. & Amanat & $\begin{array}{l}\text { a. Kejar dan raihlah mimpimu, tetap melangkah walaupun menjalani } \\
\text { pahit, getir, manis, gagal, dan sukses. } \\
\text { b. Waktu akan memberikanmu pemahaman, kebingungan, } \\
\text { kegembiraan, dan penyesalan. Dari sinilah kita akan mendapatkan } \\
\text { pengalaman yang berharga dalam kehidupan. }\end{array}$ \\
\hline
\end{tabular}

\section{E. KESIMPULAN}

Tema dalam novel "Guru Aini” yaitu tentang keberanian dan hak yang sama dalam mendapatkan pendidikan. Tokoh dalam novel "Guru Aini" adalah Desi, Aini, Bu Marlis, Runding Ardiansyah, Ayah Desi, Ibu Desi, Abang-abang Desi, Salamah, Ibu Rektor, Rizki, Anwar Adat, Nelayan, Seorang anak buah kapal, Ibuibu dan putrinya, Bocah gembil, Nurazizah, Pria-pria berpakaian rapi, Pria-pria berpaiakan kumal,, Knek Bus, Ibu Sumiati, Pak Abu Sidik, Pak Tabah, Enun, Sadi'ah, Djumiatun, Anisa, Boi, Ja'faruddin, Debut Awaludin, Pak Abnun Kholidin (Kepala Sekolah), Bu Lusinun, Bu Amanah, Guru Laila, Dinah, Pak Syaifulloh, Nadhirah, Afifah, Pak Cik, Mak Cik Nur, 3 Pelayan Warung Kopi, dan Sila. Latar dalam novel "Guru Aini" terdiri dari latar tempat, waktu, sosial dan suasana. Latar tempatnya: di sebuah rumah, di rumah desi, di kelas, di bus, di losmen, di terminal, di pelabuhan, di atas kapal, di jembatan, di dermaga, di depan 
rumah dinas, di atas motor, di pasar, di sekolah. Latar waktunya: di sore hari, malam hari, dan pagi hari. Latar sosialnya: tradisi yang ada pada masyarakat Tanjong Hampar. Dan latar suasananya: bahagia, menegangkan, bersedih, terharu, mengerikan, damai, dan kecewa.

Alur dalam novel "Guru Aini" adalah alur maju karena kisah perjalanan seorang perempuan dalam meraih cita-cita sehingga mencapai kesuksesan. Sudut pandang dalam novel "Guru Aini” adalah sudut pandang orang ketiga serba tahu, karena pengarang menceritakan kehidupan orang lain dengan nama tokoh itu sendiri. Gaya bahasa yang digunakan dalam novel "Guru Aini” adalah menggunakan bahasa Indonesia yang baik dan ada juga bahasa-bahasa yang menggunakan majas untuk memperindah suatu cerita Amanat yang terkandung dalam novel "Guru Aini" adalah kejar dan raihlah mimpimu, tetap melangkah walaupun menjalani pahit, getir, manis, gagal, dan sukses.

\section{F.SARAN}

Sebelum peneliti menganalisis sebuah novel sebaiknya peneliti mempelajari unsur-unsur yang terkandung dalam karya sastra tersebut sehingga memudahkan peneliti dalam menemukan unsur intrinsiknya. Bagi pembaca diharapkan bisa lebih memahami unsur-unsur yang terkandung dalam karya sastra salah satunya karya novel supaya mempermudah pembaca mencari tema, tokoh dan penokohan, alur, sudut pandang, gaya bahasa serta amanat yang terkandung dalam karya yang dibaca. Bagi peneliti selanjutnya semoga bisa menjadi sumber referensi untuk pedoman penelitian.

\section{DAFTAR PUSTAKA}

Abrams, M.H. 1971. A Glossary of Literary Terms. New York: Holt, Rinehart, Inc.

Atmazaki. 2007. Ilmu Sastra Teori dan Terapan. Padang: UNP Press.

Ahmad, Tanzer. 2009. Pengantar Metode Penelitian. Yogyakarta: Teras.

Ali Imron dan Farida Nugrahani. 2017. Pengkajian Sastra Teori dan Aplikasi. Surakarta: CV. Djiwa Amarta.

H.B. Jassin. 1985. Kesusastraan Indonesia Modern dalam Kritik Dan Essei. Jakarta: PT. Gramedia. 
Nasution. 2003. Metode Penelitian Kualitatif Naturalistik Kualitatif. Bandung: Tarsito.

Pandu Dian, DKK. Analisis Struktural Novel O Karya Eka Kurniawan. file:///C:/Users/ACER/Downloads/6786-13274-1-SM.pdf. Diakses 1 Juli 2021.

Rahmanto, Bernardus. 2011. Metode Pengajaran Sastra. Yogyakarta: Kanisius.

Sudjono, Anas. 2011. Pengantar Evaluasi Pendidikan. Jakarta: PT Raja Grafindo Persada.

Sari, Maria Ratih Pramita. Analisisis Unsur Instrinsik Dalam Novel Bad Romance Karya Equita Melianda. 2019. https://repository.usd.ac.id/35352/2/121224044_full.pdf. Diakses 1 Juli $\underline{2021}$.

Saryono. 2013. Metodologi Penelitian Kualitatif. Nuha Medika.

Semi, M. Atar. 1988. Anatomi Sastra. Padang: Angkasa Raya. 